\title{
PSYCHE.
}

\section{ON THE LIFE-HISTORIES AND IMMATURE STAGES OF THREE EUMOLPINI.}

BY STEPHEN ALFRED FORBES, NORMAL, ILLINOIS.

\section{[ With Plate 1.]}

The three species to which this paper is devoted (Coluspis brunnea Fab., Paria aterrima Oliv., and Scelodonta pubescens Mels.), live underground in the larval stage, and feed upon the roots of the strawberry (Fragaria vesca $\mathrm{L}$.). The larvae of all three often occur in the same localities and situations; they are extremely similar in general appearance, two of them (Paria and Scelodonta) being, indeed, almost indistinguishable; and their food-plants and food-habits are identical. They have consequently not been discriminated heretofore, even where they have been collected in considerable numbers and studied with some care; and their life-histories, as far as made out, have very naturally fallen into some confusion.

The following account is based upon almost continuous observation of one of the species, upon breeding experiments with all three, and upon numerous collections of all, made from August I882 to December i 883 , mostly in southern Illinois, where all are abundant in strawberry fields.

\section{Colaspis brunnea Fab.}

\section{Literature.}

The first undoubted reference to an immature stage of this beetle, which I have found, is in the 3 rd report of the state entomologist of Missouri (C. V.
Riley), for 1871 , p. $81-84$, in which the larva is described and figured, and record is made of the fact that it feeds upon the roots of the strawberry. A brief outline of its life-history is also given, but in terms to show that it was not at that time distinguished from the larva of Scelodonta.

In his report as state entomologist for the following year, p. 34, Mr. Riley again described this larva from numerous specimens, and figured the dorsal and ventral aspects of the head, a separate mandible, and one of the ventral segments. The description given of the mandible and of the anal segments, and the figure of the former, do not apply exactly to the larva of Colaspis, and it is possible that the specimens upon which this second description was based belonged to one of the other species.

In the American entomologist for I88o, v. 3, p. 243, Mr. Riley repeats his original figures of the Colaspis larva ; and this form has since been mentioned frequently in various economic publications, but without any further additions to our knowledge, either of its characters or of its history. The pupa has remained hitherto unknown.

\section{Description.}

Larva. (Pl. I, figs. 7-8.) This species is 3 to $4 \mathrm{~mm}$. long by one-half that width, white throughout, except the 
head and the first segment, which are a pale, yellowish brown. The first segment is leathery and smooth above, and as long as the two following together; but each of the remaining eleven segments is marked on the back by about three transverse dorsal folds, which terminate on the sides in large, low elevations, pointed-ovate in form (the pointed ends being upwards), one to each segment of the body except the first and the last.

The first spiracle is larger than the remaining eight, and placed between the first and second thoracic segments. The others are situated at the lower ends of the ovate elevations mentioned above, and just within a tortuous longitudinal groove, which separates these elevations from a series of prominent tubercles which extend along the sides, one tubercle to each segment. Still beneath the first mentioned row of tubercles is another longitudinal groove, and a second series of tubercles; and these again are separated from the transverse ventral ridges by still another irregular longitudinal groove. Finally, the ends of these ventral ridges are cut off obliquely by a series of grooves, each extending from before backwards and inwards, thus forming a fourth series of elevations, on a line with the legs.

In Colaspis, the elevations of this last series have the form of thick, fleshy tubercles which project downward beyond the general ventral surface, each bearing about ten hairs of varying lengths, the three or four longest of which are longer and stouter than any others on the larva. The hairs on the ventral ridges between these tubercles form an unbroken row. They are about nine in number, alternately longer and shorter, with very many short ones intermingled; the longest being about as long as the corresponding segments. The twelfth ventral segment (fig. $7 \mathrm{E}$ ) is deeply and widely emarginate posteriorly, divided, in fact, into two triangular plates, between which the unusually developed thirteenth segment appears. These lateral plates are fringed with spines on the posterior two-thirds of their inner margin. The thirteenth or anal segment is likewise longitudinally divided beneath.

These two segments taken together are about one and a half times the length of the preceding one; and their dorsal arches are likewise relatively elongate, being scarcely, if at all, shorter than the next segment in advance.

The legs are about as long as the thoracic segments to which they are attached, and are white, with the exception of the claws, which are dark brown at the tips. They are provided with a few slender white hairs, which become shorter and more spine-like toward the end of the leg.

The head is smooth, somewhat flattened in front, with a few slender, scattered hairs. The clypeus is trapezoidal, and the anterior edge of the labrum (fig. $7 \mathrm{D}$ ) is convex. The antennae (fig. 7A) are situated just outside the bases of the mandibles. They are minute, white, four-jointed, the two basal joints short and quadrate, the second 
and third together as long as the first. The outer distal angle of the third joint is continued as a cylindrical process, which reaches to the end of the joint following.

The mandibles (fig. $7 \mathrm{C}$ ) are rather narrow (the width being about twothirds the length), strongly curved, comparatively broad, and obtuse at tip, where they are emarginate, or sometimes trifid. Each bears two long, slender hairs at its outer base.

The cardinal and basal pieces of the maxilla (fig. $7 \mathrm{Bc}$ ) are not clearly distinct ; the maxillary lobe is stout, rounded at the tip, and convex internally, with about ten spines, of varying strength, along the inner margin, the two basal ones being very strong, and about half the length of the lobe. This last extends only a little beyond the second joint of the palpus. The palpi (fig. $7 \mathrm{Bd}$ ) are prominent and fourjointed, the third joint longest, about equal to the first and second together, and the fourth slender and cylindrical.

The labium (fig. $7 \mathrm{Bb}$ ) is thick and quadrate, without distinct palpigerous tubercle, and bears on its under surface two slender, cylindrical, unarticulate palpi (fig. $7 \mathrm{Ba}$ ), which are about as long as the third joint of the maxilla, and taper slightly distally.

Pupa. The pupa is $3.5 \mathrm{~mm}$. long by $2.5 \mathrm{~mm}$. wide; white, except the eyes and the mandibles, which show through the outer envelop red or black.

The front of the head is set with a few long, stout hairs, articulated upon slender, conical tubercles; and three similar rows of hairs appear upon the thorax, one near the anterior border, another near the posterior, and a third intermediate. Six other hairs occur upon the scutellum, and a row of about six or eight borders each one of the abdominal segments above.

The anterior inferior angle of the tibiofemoral articulation of each leg bears a stout, curved hook, that on the first pair of legs being very small. Each of these articulations is likewise armed with two long hairs borne upon slender, conical tubercles. The sheaths of the antennae are tuberculate externally,

The posterior segments of the abdomen are peculiarly armed. The last (fig. $7 \mathrm{~F}$ ) terminates in two simple, incurved hooks, and bears in front of these a pair of stout lateral spines, projecting directly outwards; while a similar but smaller pair of backwardprojecting spines is borne by the penultimate.

\section{Life-History.}

The imago is said by Dr. Fitch to appear in the latter part of June, continuing through the month of July. Mr. Riley, in his third Missouri report, says that pupation commences in June, the beetles appearing in that month and continuing to issue from the ground until fall

Larvae of this species were first seen by me in southern Illinois on I9 May, at which time they were about half-grown. On 28 June, full-grown larvae and imagos were found in the earth, in strawberry fields, the imagos having, of course, just transformed. Adults again occurred in the earth on 9 July, but by I 8 July all had emerged. As early as 
4 July they appeared in stubble fields, and were found from the beginning in sweeping the leaves of the strawberry, where they continued common until I August. They were also taken in vineyards, feeding upon the leaves of grapes, on is July.

Careful and repeated search in all situations suited to their development failed to discover either larvae or pupae again during the year; and I have no doubt that the species is single-brooded, and think that it completes its transformations, under ordinary circumstances, by I August.

Numerous collections made in October, November and December, throughout the region where these beetles appeared abundantly earlier in the year, failed to discover a single specimen among the thousands of hibernating insects encountered; and I am of the opinion that this species hibernates rarely, if ever, as an imago, but believe that it deposits its eggs in late summer or autumn, probably in the earth about strawberry roots.

Paria aterrima Oliv. (Pl. I, fig. I, 4.)

\section{Literature.}

The larva of this chrysomelid was first noticed in 1880 , in an article by Prof. A. J. Cook, of Michigan, printed originally in several western agricultural journals, and later in the report of the Michigan state horticultural society for that year, p. 293. This newspaper description was republished in the American entomologist for October I 880 , v. 3, p. 242243 , and a few remarks were added by Mr. Riley, com- paring the characters of the larva, as described by Prof. Cook, with those supposed to distinguish Colaspis.

Prof. Cook's article, in a revised form, was also published by the State agricultural society of Michigan, in its report for the year ending August 3ist, I88o, p. 273. Another account of the larva, with some additional notes upon its habits, was given by the present writer in the Transactions of the State horticultural society of Illinois, for 1882 , p. 199, and again, in the following year, $i_{n}$ a paper on Insects affecting the stiawberry, published in the Transactions of the Mississippi valley horticultural society for 1883 , p. 77 and also issued as a separate pamphlet. This description was somewhat fuller than any preceding, and was illustrated by a figure of the larva made from a cameralucida drawing, but still insufficient to distinguish it clearly from the larva of Colaspis, and applying equally well either to Paria or to Scelodonta.

\section{Description.}

Larva. Agreeing closely in size, form, and general appearance with the larva of Colaspis, this species may be distinguished by the following details : The brown hairs of the ventral ridges are few and short, all shorter, in fact, than the corresponding segments. The ends of these segments are cut off by oblique grooves, and have the form of triangular tubercles, with their apices inwards; but these are not raised at all above the general ventral surface. Each of them bears from five to seven hairs, of which about three are longer than 
the others. The hairs of the median portion of the ridge are separated into two groups by a narrow, median, naked strip. The vent is surrounded by a circlet of ten short hairs. All the hairs of the last four segments are longer and stouter than those preceding; and those of the dorsal surfaces of these segments are likewise more numerous The dorsal arches of the last two abdominal rings are broken into four prominent tubercles, which are sometimes slightly blackened, and bear especially strong spinous hairs.

The eyes are represented by a small cluster of a varying number of pigment specks, situated at less than the length of the antenna above its base.

The antennae are three-jointed, very short, not twice as long as wide, the length of the basal joint being just about its width. The cylindrical process of the penultimate joint is segmented off, forming an apparent accessory article beside the terminal one. The clypeus is about as long as the labrum; and upon the middle of the upper surface of the latter are four long hairs, arranged transversely; and at the inferior edge of the posterior surface are eight strong hooks or spines, projecting inwards and backwards. The maxillary palpi are strong and thick, the two basal joints being broader than long, the third about as long as wide, and the fourth ovate. The tip of the third joint extends scarcely beyond the end of the blade of the maxilla. The latter is not longer than broad, and is armed with about ten stout, blunt spines at its inner margin.
The general form of the mandibles (fig. 6B), seen from above, is triangular, the length being scarcely greater than the width at their base. The tip, seen from beneath, is obtuse and more or less conspicuously emarginate, often decidedly lobed, in which case the lobes are equal. It is never trifid, and never acute. Occasionally this bilobate character of the mandibles is indicated by a longitudinal groove, which scarcely renders the tip emarginate.

The anal segment of this larva is used as a proleg, the grub looping along on a smooth surface after the manner of a phalaenid larva.

Pupa. The pupa may be distinguished by differences in the armature of the posterior segments of the abdomen, especially the last (fig. 6A). This terminates in a pair of brown, chitinous hooks, which curve dorsally, instead of inwards as in Colaspis, each being furnished with a strong, erect tooth or spine arising from the upper side of the base. From the middle of the concave margin of each hook springs a long slender hair. The spines in front of these anal hooks project directly backwards. This pupa is further distinguished from that of Colaspis by the absence of spines upon the anterior inferior angle of the tibio-femoral articulation of the first and second pairs of legs.

\section{Life-History.}

Last April the adult beetles were found not uncommonly in strawberry fields in southern Illinois, having evidently lately emerged from their winter 
quarters; but the most careful search of fields infested by root-worms yielded no Paria larvae. On i 8 May, the adults were again obtained in considerable numbers, by sweeping the foliage of strawberries; and on 55 June a few were seen in the ground about the roots of the plants. On 20 July, larvae and pupae of this species were found among the strawberry roots, adults also occurring on the foliage ; and on 26 July all stages were sent me from Lansing, Michigan.

From I to ro August, larvae, pupae and imagos were collected in southern Illinois. On I I August, the larvae and pupae were noticeably less common than before, but the imagos were now more abundant on the leaves, and several were taken from cavities in the earth. Some larvae and pupae taken from the ground on I August, were kept in earth (after careful study of the living specimens for subsequent identification) until they transformed, one beetle emerging on I I August.

On 24 August, the earth was examined and three more adults were found. These were the last immature examples seen, only scattering adults occurring in our collections during September, October, and November. On 8 December they were taken in abundance under leayes and rubbish on the ground, hibernating in the strawberry fields.

Evidently, here we get no glimpse of a second brood, either early or late, but find the beetles wintering as mature insects, probably laying their eggs in the ground in June, the adults appearing again late in July and in August.
Scelodonta pubescens Mels.

$$
\text { (P1. I, fig. 2.) }
$$

The larva and pupa of this species have hitherto remained unknown.

\section{Description.}

Larva. The description of the larva of Paria aterrima, given above, will answer for this species also, point by point, with the exception of characters drawn from the mandibles (fig. $5 \mathrm{C}$ ). The tips of these are usually entire, and rather obtuse, although rarely irregularly lobed, or trifid, the central lobe being then much the most prominent. The inner edge of the mandible is excavated on the distal third, like that of Paria.

Pupa. (Pl. I, fig. 3.) The pupa of this species is indistinguishable from that of Paria, except by the fact that the terminal hooks of the abdomen (fig. 5 $A)$ are smaller, more slender, destitute of the basal spine and of the hair springing from the convex margin.

$$
\text { Life-History. }
$$

My first specimens of the larva of this species were obtained in August 1882, two half-grown individuals and one adult beetle occurring in a small collection of insects made at that time in southern Illinois. On I I September, large and small larvae were found devouring strawberry roots, and a single adult was obtained by sweeping in the field. On 9 November, full-grown larvae were abundant, all having gone into winter quarters in oval cavities in the earth. They occurred at various depths, from 2.5 to $10 \mathrm{~cm}$, and often at con- 
siderable distances from the plants on which they had been feeding.

Many hundreds of these larvae were unearthed in November, but not a pupa was found, nor a single adult. Two of the latter were obtained, however, in strawberry fields, in December, showing that a sprinkling of them hibernate as imagos. That it is only a sprinkling was clear, not only from the great numbers of mature larvae of this species in the ground at the time, but likewise from the fact that adults of Paria aterrima were then collected by the hundred, although the strawberry roots had been much less seriously attacked by that species than by Scelodonta. Early in the following April the larvae were still secure in their subterranean retreats, no pupae yet appearing. On I6 April, two adults were taken, but these were the only ones captured during several days of careful and active field work.

A number of hibernating larvae were placed in boxes of earth at this time, for the purpose of determining the period of their transformations. On 9 May they were found still in their winter condition, but on 20 May pupation was well under way; and about half those in the field were also now in the pupa stage. A thorough search yielded no adults, and no young larvae.

On 7 June, a single adult emerged from those under observation, and the next day three more appeared. The day following, the earth was examined carefully, and fifteen adults were found, all but two still in their cells. With these were three larvae (one of which was dead) and a single pupa. On 15
June, many adults were found in the ground, in the fields, with larvae and pupae, but no adults could be got by sweeping the strawberry vines, and careful search of previously infested fields, made late in July and early in August, yielded but a single imago of this species.

Adults emerging in the breeding cages were observed to feed freely upon the leaves of the strawberry, making small, round holes though the leaf, of about the diameter of their own bodies.

The above data enable us to say definitely that this insect is single-brooded, like its congeners; that it hibernates as a full-grown larva, in oval cells in the earth, a few beetles of the preceding brood likewise sometimes surviving the winter; that tha change to pupa occurs in May; and that the adults appear above ground in June. In July, doubtless, the eggs are laid, probably in the ground, the young larvae- attacking the roots of the strawberry in that month and in August.

\section{Comparison of Life-Histories.}

It will. now be interesting and profitable to bring together, side by side, the life-histories of these three companion species.

We have, in these root-worms, three related species, attacking the same part of the same plant in precisely the same way, at the same stage in their development; and strictly dependent upon this plant (as far as is known) for their continued existence. They are, moreover, all native to the region in which they now occur, and have probably fed upon 
the wild strawberry from time immemorial.

One would say that here were all the conditions of a most determined struggle for existence, in which one or more of these species must succumb. It is indeed interesting to see how the issue is evaded, and an adjustment reached by which competition is reduced to a minimum. The Colaspis larva makes the earliest attack upon the plant, beginning its work upon the root certainly as early as the first of May (half-grown individuals having been taken on the 15 th), and finishing in June, all being of full size and preparing to pupate by the end of that month. Next comes Paria, in July and August, neither extreme of its period being exactly defined by our observations; and finally comes Scelo. donta, adults of which were copulating on I July, young larvae occurring $7 \mathrm{Au}$ gust. As far as now known, the Scelodonta larva is left in undisturbed possession during the remainder of the year; although there is a break in our observations for October. Certainly by November it has completed its work, and retired, full-grown, and ready to transform, into its subterranean cell.

It seems clear, furthermore, that this curious succession of periods is related to a difference of habit with respect to hibernation. Undoubtedly Scelodonta winters as a larva, and Paria as an adult. As Colaspis larvae were only half-grown on ${ }_{5}$ May, they very probably hatched from the egg that spring; and as the adult Colaspis emerged about two months before the new brood of Paria, it seems hardly possible that both could have developed from eggs laid that spring; but it is much more likely that Colaspis hibernates in the egg. On this hypothesis, we shall have the eggs of Colaspis deposited in autumn, those of Paria in spring, and those of Scelodonta in midsummer, the first species hibernating in the egg, the second as an adult, and the third as full-grown larva, with the necessary result that their attacks upon their common food plant are delivered successively.

The immense advantage derived from this arrangement is evident, when we reflect that by this means as many of each of the species are fed upon the surplus structures and supernumerary individuals of the strawberry (that plant being a continuous grower), as it would be possible to maintain of all three if they came into simultaneous competition.

\section{COLLECTION AND PRESERVATION OF DIPTERA.}

BY SAMUEI, WENDELI, WIIIISTON, NEW HAVEN, CONN.

From dearly purchased experience I have learned the necessity of care in the collection and preservation of entomological specimens, and it may be that a few hints will be of service to the collectors of diptera and similar insects.

For collecting I use a cyanide-bottle, 


\section{Explanation of Plate i.}

Fig. I. Paria aterrima Oliv.

Fig. 2. Scelodonta pubescens Mels.

Fig. 3. Pupa of Scelodonta pubescens.

Fig. 4. Head of Paria aterrima, front view.

Fig. 5. Larval and pupal structures of Scelodonta.

A, tip of abdomen of pupa, lateral view; with figure of anal hook, more enlarged. B, last abdominal segments of larva, viewed from beneath. $\mathrm{C}$, mandible of larva.

Fig. 6. Larval and pupal characters of Paria.

A, tip of abdomen of pupa, lateral view. B, mandible of larva.

Fig. 7. Larval and pupal characters of Colaspis.

A, antenna of larva. B, labium and maxillae. C, mandible.

D, labrum. E, last abdominal segments of larva, viewed from beneath. F, tip of abdomen of pupa, ventral view.

Fig. 8. Larva of Colaspis brunnea Fab. 
Psyche, 1884, v. 4.

FIG. I.

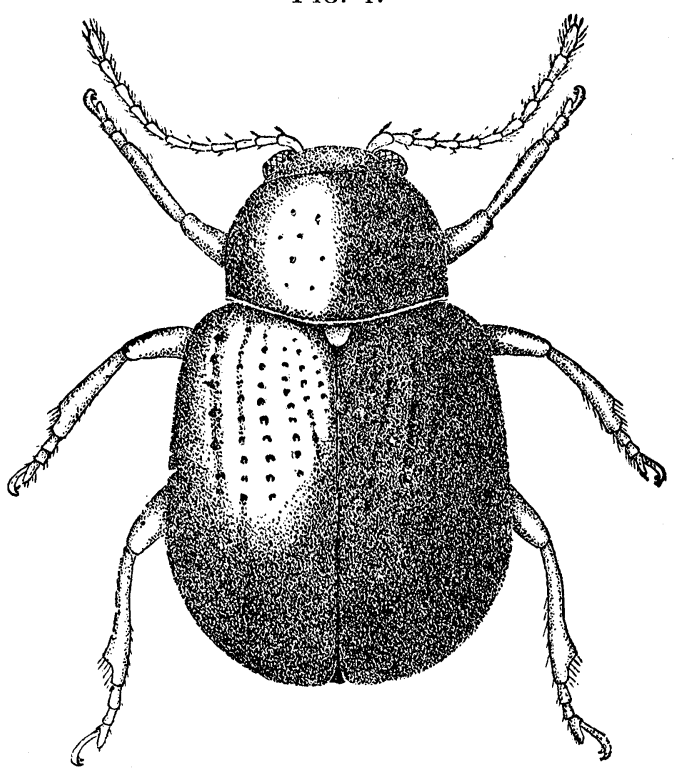

Fig. 3.

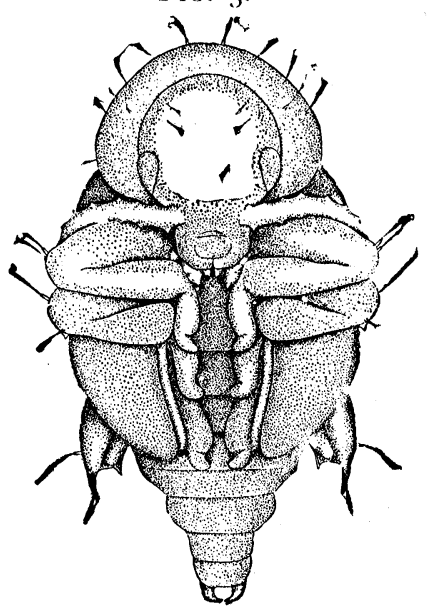

FIG. 7 .
FIG. 2.

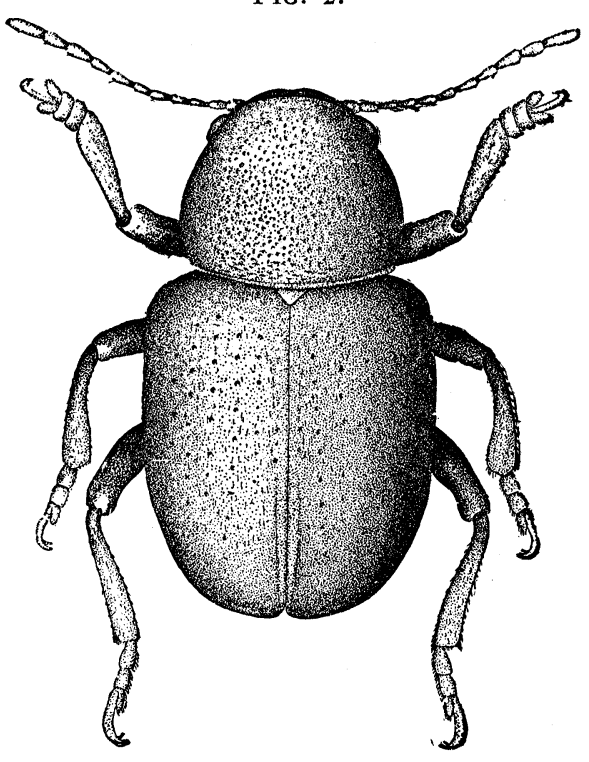

FIG. 5 .

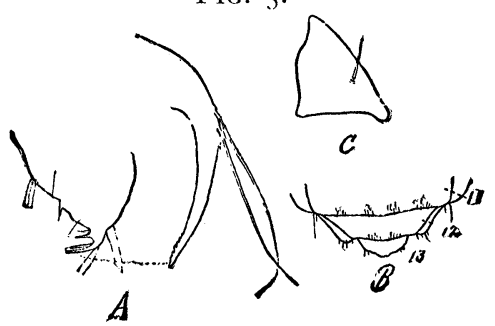

FIG. 6.

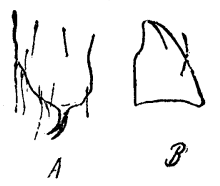

FIG. 8.

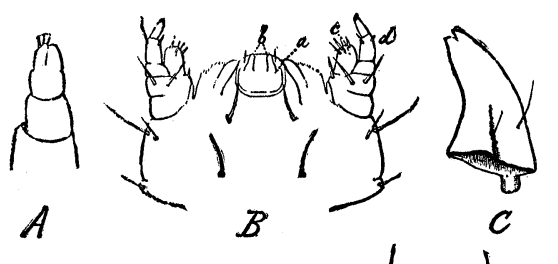

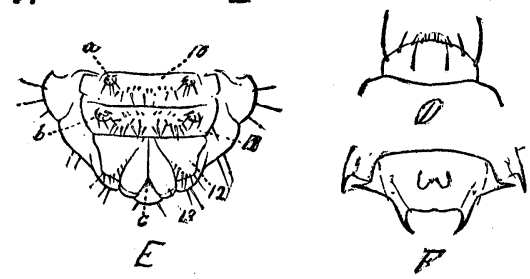

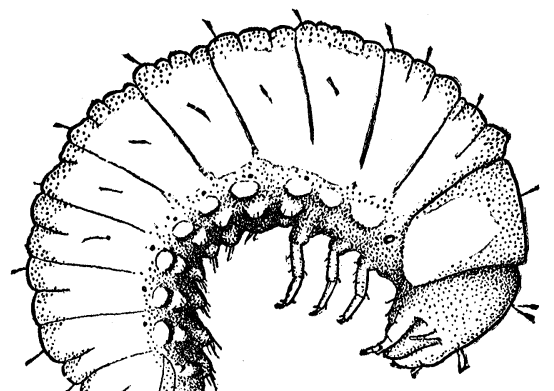



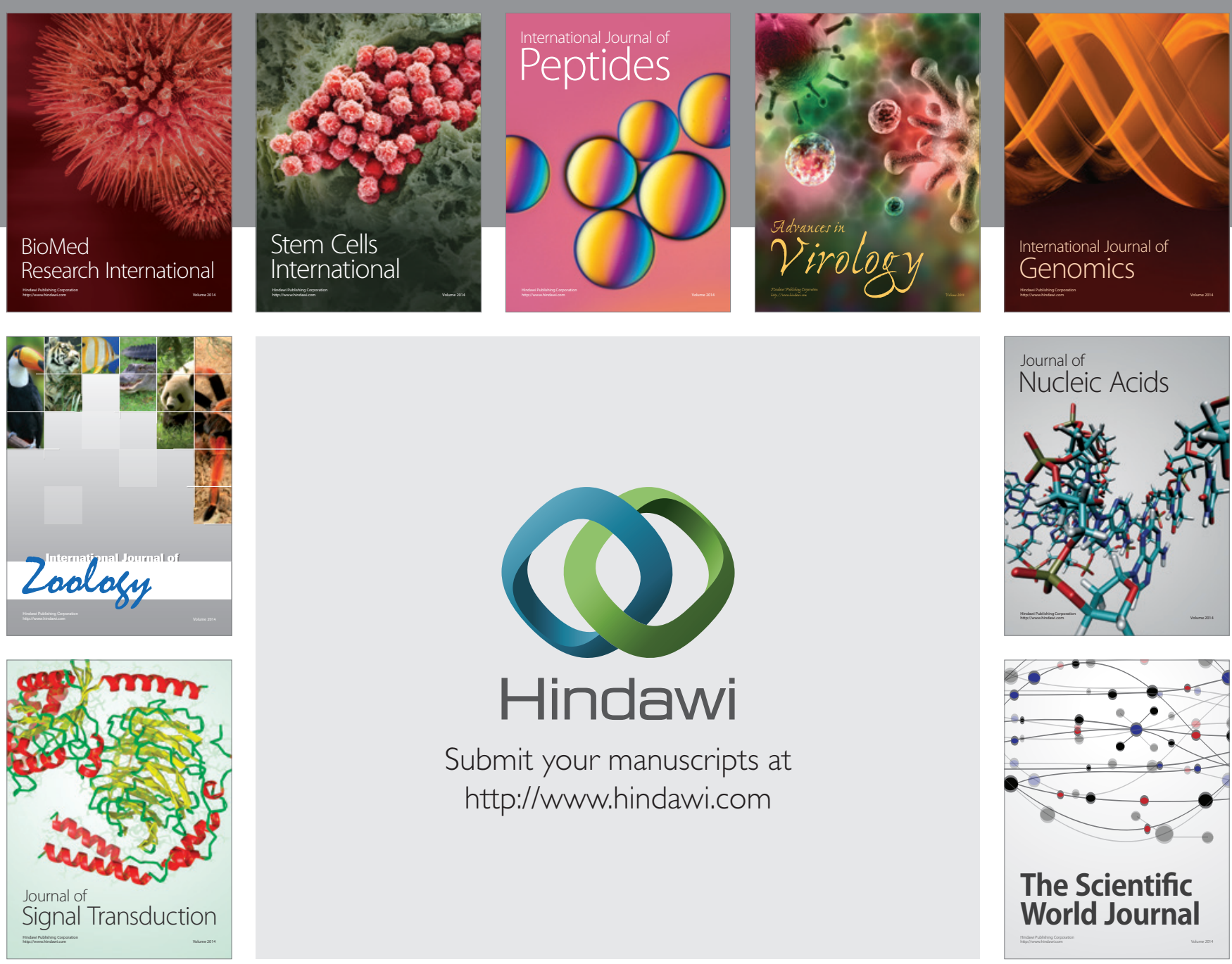

Submit your manuscripts at

http://www.hindawi.com
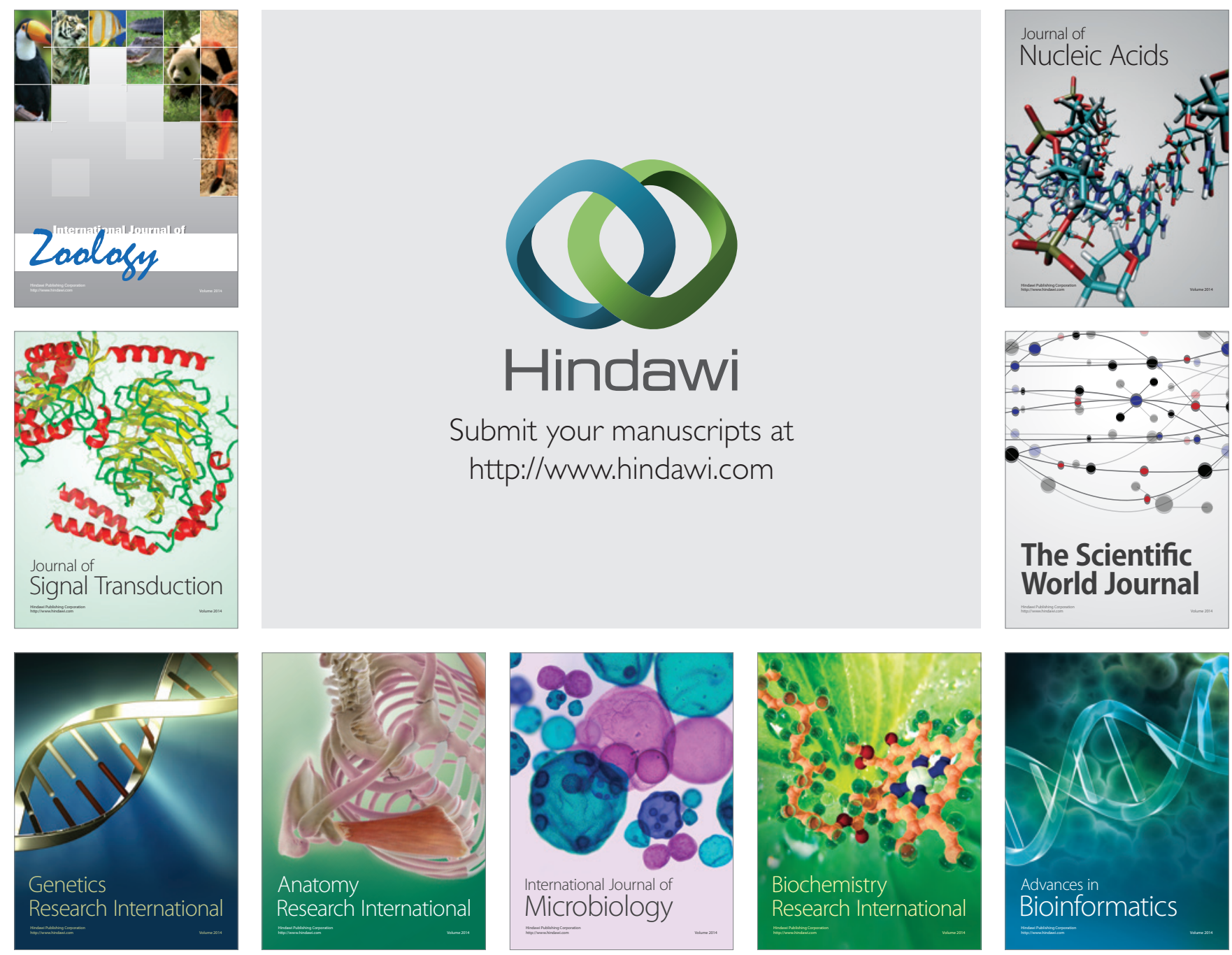

The Scientific World Journal
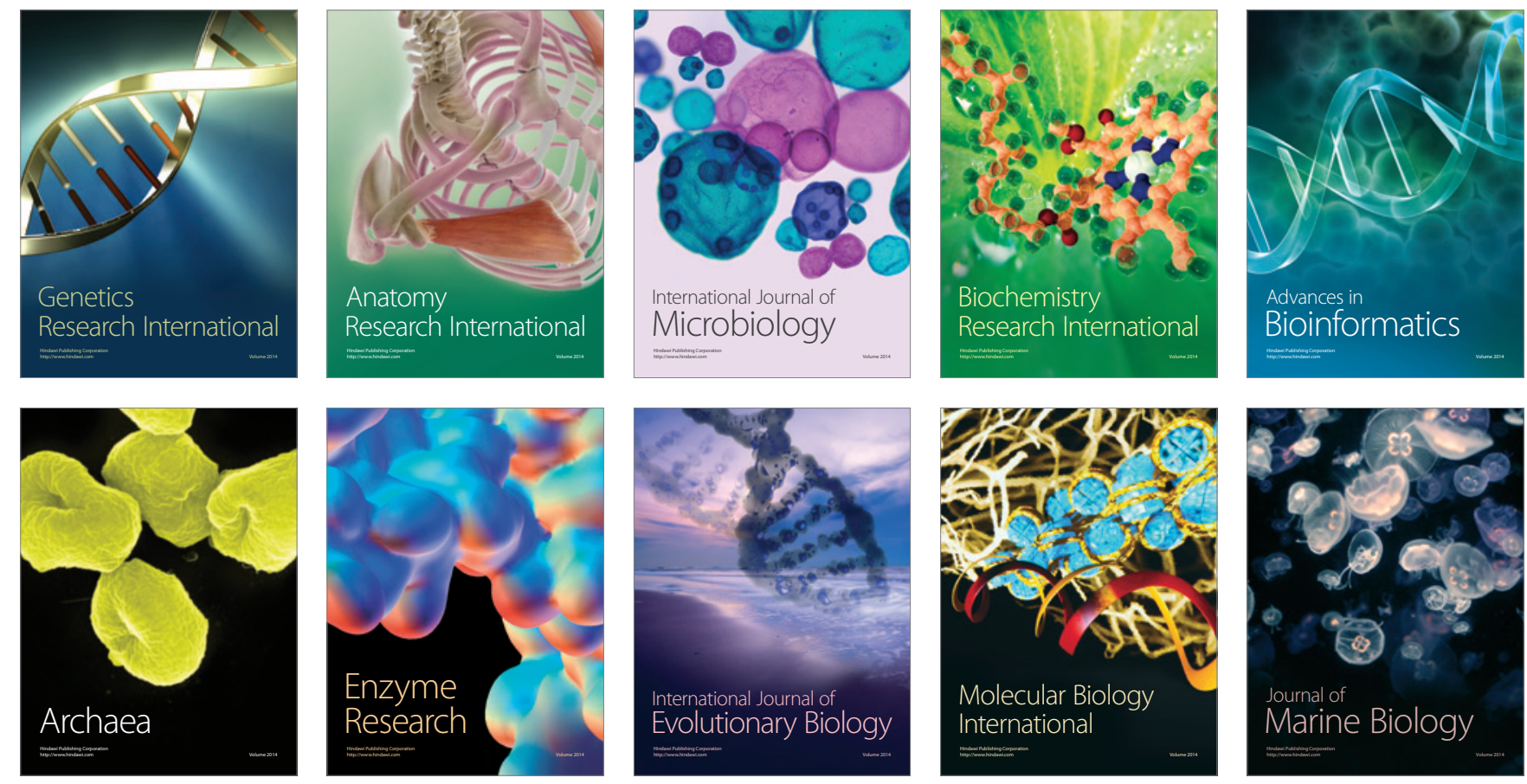